\title{
PREFERENSI MASYARAKAT TERHDAP PERMINTAAN LISTRIK DI PURWOKERTO (Evaluasi Terhadap Kebijakan Listrik Prabayar)
}

\author{
Rusmusi IMP, Nunik Kadarwati dan Irma Suryahani \\ Fakultas Ekonomi dan Bisnis \\ Universitas Jenderal Soedirman Purwokerto \\ Email: rusmusiimp@gmail.com,n_kadarwati@yahoo.co.id_danirmajoe@gmail.com
}

\begin{abstract}
Not all of the new PLN customers in the Purwokerto Branch use prepaid electricity, while some still use postpaid electricity. The purpose of this study is to compare the characteristics of postpaid and prepaid customers in terms of customer satisfaction, determinants of electricity demand and community preferences in choosing both types of PLN Indonesia products. The method used is multiple linear regression. The results of this study are 1) there is no correlation between the characteristics of respondents with the satisfaction of respondents, whereas for prepaid customers the results are obtained that only the characteristics of gender customers have a correlation with respondent satisfaction. 2) Based on the results of the T-test test it is known that there are differences, the level of customer satisfaction with services in PT PLN (Persero) Purwokerto Area. 3) The level of importance and level of satisfaction on the dimensions of reliability, responsiveness, assurance, tangible and empathy for prepaid electricity customers is higher than the level of interest and satisfaction level of postpaid electricity customers.4) Based on the results of the T-Test, the demand for prepaid electricity provides greater satisfaction than postpaid electricity.
\end{abstract}

Keywords: Satisfaction, Customers, PLN, Preferences, Postpaid, and Prepaid.

\begin{abstract}
Abstrak
Jumlah pelanggan baru PLN di Cabang Purwokerto tidak semuanya menggunakan listrik prabayar sebagian masih mengunakan listrik pascabayar. Tujuan penelitian ini untuk membandingkan karakteristik pelanggan pascabayar dan pelanggan prabayar dalam hal kepuasan pelanggan, determinan permintaan listrik dan preferensi masyarakat dalam memilih kedua jenis produk PLN Indonesia. Metode yang digunakan adalah regresi linier berganda. Hasil dari penelitian ini adalah 1) tidak ada korelasi karakteristik responden dengan kepuasannya responden, sedangkan untuk pelanggan prabayar didapatkan hasil bahwa hanya karakteristik pelanggan jenis kelamin yang memiliki korelasi dengan kepuasan responden. 2) Berdasarkan hasil pengujian T-test diketahui bahwa ada perbedaan, tingkat kepuasan pelanggan terhadap pelayanan di PT PLN (Persero) Area Purwokerto. 3) Tingkat kepentingan dan tingkat kepuasan pada dimensi realibility, responsiveness, assurance, tangible dan emphaty pada pelanggan listrik prabayar lebih tinggi daripada tingkat kepentingan dan tingkat kepuasan pelanggan listrik pascabayar.4) Berdasarkan hasil T-Test, permintaan listrik prabayar memberikan kepuasan yang lebih besar daripada listrik pascabayar.
\end{abstract}

Kata Kunci: Kepuasan, Pelanggan, PLN, Preferensi, Pascabayar, dan Prabayar. 


\section{PENDAHULUAN}

Listrik bisa dikonversikan menjadi energi lain untuk menunjung aktivitas manuasia seperti menggerakan motor, lampu penerangan, dan juga untuk memanaskan suatu benda. Energi yang dihasilkan dapat berasal dari berbagai sumber seperti air, minyak, batu bara, panas bumi dan panas matahari. Listrik merupakan kebutuhan manusia yang sangat penting. Sejak listrik ditemukan, kehidupan manusia mengalami kemajuan yang sangat pesat dalam berbagai bidang.

Listrik telah menjadi kebutuhan yang mendasar untuk berbagai aktivitas manusia. Tidak dapat dipungkiri bahwa energi listrik memegang peranan yang dominan dalam kehidupan masyarakat sehari-hari. Bidang teknologi khususnya elektronika menjadi faktor pendorong utama meningkatnya kebutuhan listrik masyarakat. Hampir di semua aktivitas yang dilakukan baik di rumah tangga, perkantoran, pertokoan, pabrik, fasilitas umum, sosial dan sebagainya sangat bergantung pada keberadaan listrik.

Dari waktu ke waktu jumlah pengguna/pelanggan listrik di Indonesia bertambah seiring dengan berkembangnya waktu. Pertambahan jumlah ini seiring dengan bertambahnya jumlah penduduk yang berarti betambahnya jumlah kebutuhan listrik masyarakat.

Di Indonesia Perusahaan Listrik Negara (PLN) sebagai perusahaan penyedia listrik negara menyediakan 2 (dua) fasilitas untuk dinikmati para konsumen yaitu pascabayar (non token) dan yang terbaru adalah prabayar (token). Pascabayar adalah pengguna diperbolehkan membayar tagihan setelah menggunakan layanan listrik PLN. Artinya pengguna boleh menggunakan layanan listrik PLN terlebih dahulu, kemudian setelah penggunaan selama satu bulan akan muncul tagihan. Tagihan ini dihitung berdasarkan penggunaan KWH listrik yang tertera di meteran. Prabayar adalah layanan listrik yang memungkinkan pelanggan untuk mengendalikan sendiri penggunaan listriknya sesuai kebutuhan dan kemampuan. Seperti halnya pulsa isi ulang pada telepon seluler, pada sistem listrik pintar, pelanggan terlebih dahulu membeli pulsa (voucher/token) listrik isi ulang melalui gerai ATM sejumlah bank atau melalui loket-loket pembayaran tagihan listrik online. (http://www.pln.co.id).

Tabel 1. Jumlah Pelanggan dan Penjualan KWH Listrik PLN di Indonesia (2011-2017)

\begin{tabular}{lll}
\hline Tahun & Pelanggan & Gwh \\
\hline 2011 & 45.900 .000 & 158.000 \\
2012 & 49.800 .000 & 174.000 \\
2013 & 54.000 .000 & 187.500 \\
2014 & 57.500 .000 & 198.600 \\
2015 & 61.200 .000 & 202.800 \\
2016 & 64.300 .000 & 216.000 \\
2017 & 66.600 .000 & 146.400 \\
\hline
\end{tabular}

Sumber : Perusahaan Listrik Negara, PT (Persero) PLN

Dari tahun ke tahun, jumlah pelanggan listrik prabayar PLN terus meningkat. Pada tahun lalu, PLN telah menambah 5,3 juta pelanggan baru untuk listrik prabayar. Dengan total pelanggan 13,1 juta, itu berarti 24,3 persen dari total pelanggan PLN sebanyak 5,39 juta sudah memakai listrikprabayar. Pemanfaatan listrik prabayar menguntungkan pelanggan karena dengan menggunakan layanan tersebut pelanggan dapat mengatur pemakaian listrik dan dapat mematok anggaran biaya listrik bulanan. (liputan 6, 2014).

Sejauh ini penambahan jumlah pelanggan PLN tidak selalu identic dengan penambahan jumlah pelanggan PLN prabayar dengan jumlah tambahan yang sama. Listrik prabayar biasanya diwajibkan bagi pemasangan listrik kelompok subsidi dan berdaya kecil. Hal ini menunjukkan bahwa kebijakan pemasangan prabayar masih menjadi kebijakan yang di"paksakan" dari PLN. Bukan kebijakan tambahan bagi semua golongan masyarakat. Demikian juga dari sisi masyarakat, tidak semua menerima model pemasangan listrik prabayar.Di Purwokerto jumlah pelanggan PLN juga bertambah dari waktu ke waktu. Seperti 
halnya jumlah pelanggan Indonesia, jumlah pelanggan di Indonesia, jumlah pelanggan Purwokerto sebagai kota menengah yang sedang berkembang juga bervariasi. Tidak semua pertambahan pelanggan PLN baru menggunakan PLN prabayar.

\section{METODE PENELITIAN}

\section{Cara pengambilan Sampel}

Metode yang digunakan dalam penelitian ini adalah dengan menggunakan metode cluster random sampling digunakan untuk memudahkan pengambilan sampel. Karena seluruh pengguna listrik PLN tersebar di seluruh Kota Purwokerto maka dalam penelitian ini dibatasi pada semua pelanggan golongan Rumah Tangga yang tinggal di Kota Purwokerto saja. Metode pengambilan sampel dilakukan dengan cara membagi pelanggan pasca bayar R1 dan pelanggan pra bayar R1.

Jumlah sampel dari masing-masing daerah adalah :

Pelanggan Pasca Bayar R1 di Purwokerto = 50 Orang

Pelanggan Pra Bayar R1 di Purwokerto = 50 Orang

Total sampel 100 pelanggan

Untuk menjawab permasalahan yang telah ditentukan di atas maka digunakan analisis deskriptif dan kualitatif dengan menggunakan analisis statistik ekonometrik. Analisis regresi linear berganda dan perhitungan koefisien varian dari setiap faktor yang mempengaruhi permintaan Listrik PLN.

$\mathrm{Qw}=\mathrm{f}(\mathrm{X} 1, \mathrm{X} 2, \mathrm{X} 3, \mathrm{X} 4, \mathrm{D} 1)$

Keterangan:

$\mathrm{Qw}=$ Permintaanlistrik

$\mathrm{X} 1=$ Pendapatan pelanggan

$\mathrm{X} 2=$ Harga/tarif listrik

$\mathrm{X} 3$ = Jumlah anggota keluarga pelanggan listrik

$\mathrm{X} 4$ = Jumlah barang elektronik yang digunakan

D1 = Pascabayar dan prabayar
Secara Linear fungsi tersebut dapat dinyatakan sebagai berikut:

$\mathrm{Qw}=\beta 0+\beta 1 \mathrm{X} 1+\beta 2 \mathrm{X} 2+\beta 3 \mathrm{X} 3+\beta 4 \mathrm{X} 4+$ $\beta 5 \mathrm{D} 1$

Dalam ekonometrika pengaruh faktor-faktor lain dihitung dengan memasukkan variable acak dalam hubungan antar variable dinyatakan dalam bentuk stokastik, yaitu:

$\mathrm{Qw}=\beta 0+\beta 1 \mathrm{X} 1+\beta 2 \mathrm{X} 2+\beta 3 \mathrm{X} 3+\beta 4 \mathrm{X} 4+$ $\beta 5 \mathrm{D} 1+\mathrm{e}$

\section{KONSEP DASAR}

\section{Teori Permintaan}

Permintaan adalah jumlah dari suatu barang yang mau dan mampu dibeli pada berbagai kemungkinan harga, selama jangka waktu tertentu, dengan anggapan hal-hal lain tetap sama (ceteris paribus) (Gilarso, 2003). Permintaan atas suatu barang dapat dilihat dari dua sudut, yaitu permintaan yang dilakukan oleh seseorang/individu tertentu, dan permintaan yang dilakukan oleh semua orang didalam pasar. Oleh karenanya didalam analisis perlu dibedakan diantara kurva permintaan perseorangan dan kurva permintaan pasar.Untuk memperoleh kurva permintaan pasar haruslah kurva permintaan berbagai individu dalam pasar dijumlahkan. Permintaan seseorang atau suatu masyarakat atas sesuatu barang ditentukan oleh banyak faktor. Diantaranya faktor-faktor tersebut yang terpenting adalah harga barang tersebut, pendapatan rumah tangga dan pendapatan rata-rata 14 masyarakat, corak distribusi pendapatan dalam masyarakat, citarasa masyarakat, jumlah penduduk dan ramalan keadaan dimasa yang akan mendatang (Sukirno, 1998).

\section{Preferensi}

Preferensi konsumen adalah pilihan suka atau tidak suka oleh seseorang terhadap produk (barang atau jasa) yang dikonsumsi. Preferensi konsumen menunjukkan kesukaan konsumen dari berbagai pilihan produk yang ada (Kotler, 1997).

Menurut Nicholson (1994), hubungan preferensi diasumsikan memiliki tiga sifat dasar: 
a. Kelengkapan (completeness)

Jika A dan B merupakan dua kondisi atau situasi, maka tiap orang selalu harus bisa menspesifikasikan apakah:

1) A lebih disukai daripada $B$

2) B lebih disukai daripada $A$

3) A dan B sama-sama disukai

Dengan dasar ini tiap orang diasumsikan tidak pernah ragu dalam menentukan pilihan, sebab mereka tahu mana yang lebih baik dan mana yang lebih buruk, dan dengan demikian selalu bisa menjatuhkan pilihan di antara dua alternatif.

b. Transitivitas (transitivity)

Jika seseorang mengatakan ia lebih menyukai A daripada $\mathrm{B}$, dan lebih menyukai $\mathrm{B}$ daripada $\mathrm{C}$, maka ia harus lebih menyukai A daripada C. Dengan demikian orang tidak bisa mengartikulasikan preferensinya yang saling bertentangan.

c. Kontinuitas (Continuity)

Jika seseorang menyatakan lebih menyukai A daripada B, ini berarti segala kondisi di bawah A tersebut disukai daripada kondisi di bawah pilihan B.

Analisis preferensi konsumen adalah analisis yang bertujuan untuk mengetahui apa yang disukai dan yang tidak disukai konsumen, juga untuk menentukan urutan kepentingan dari suatu atribut produk maupun produk itu sendiri. Dengan menggunakan analisis preferensi ini akan diperoleh urutan kepentingan karakteristik produk seperti apa yang paling penting atau yang paling disukai (Oktaviani, 1996).

\section{Teori Harga}

Salah satu gejala ekonomi yang sangat penting dan berhubungan dengan prilaku petani baik sebagai produsen maupun sebagai konsumen adalah harga (Mubyarto, 1994). Dalam arti yang paling sempit, harga (price) adalah jumlah uang yang akan di bebankan atas suatu produk atau jasa. Lebih luas lagi, harga adalah jumlah dari seluruh nilai yang ditukar konsumen atas manfaat- manfaat memiliki atau menggunakan produk atau jasa tersebut (Kotler dan Armstrong, 1999).

Harga memegang peranan penting dalam mengambil keputusan jangka panjang maupun jangka pendek.Dalam jangka panjang harga-harga itu hendaknya member optimis untuk alokasi sumber daya dan kepuasan konsumen.Dalam jangka pendek, harga-harga itu harus memudahkan perdagangan dan arus peredaran yang tepat waktunya (Kustiah, dkk, 1986)

Harga suatu barang dan jumlah barang yang diperjual belikan ditentukan oleh permintaan dan penawaran dari barang tersebut.Oleh karena itu, untuk menganalisis mekanisme penentuan harga dan jumlah barang yang di perjual belikan maka perlu 7 dilakukan analisis permintaan dan penawaran atas suatu barang tertentu yang terdapat dipasar. Keadaan suatu pasar dikatakan seimbang apabila jumlah yang ditawarkan penjual padaharga tertentu adalah sama dengan jumlah yang diminta para pembeli pada harga tersebut. Harga suatu barang dan jumlah barang yang diperjualbelikan adalah ditentukan dengan melihat keadaan ekuilimbrium dalam suatu pasar. (Sukirno, 2005).

\section{Konsep Kepuasan}

Menurut oliver yang dikutip oleh J Supranto (2001: 233) kepuasan adalah tingkat perasaan seseorang setelah membandingkan kinerja atau hasil yang dirasakan dengan harapannya. Kepuasan adalah perasaan senang atau kecewa seseorang yang muncul setelah membandingkan antara persepsi terhadap kinerja atau hasil suatu produk dan harapan-harapannya (Kotler, 2002: 42).Jadi tingkat kepuasan pelanggan atau konsumen merupakan fungsi dari perbedaan antara kinerja yang dirasakan dengan harapan. Apabila kinerja dibawah harapan, maka konsumen akan kecewa. Tetapi apabila kinerja sesuai dengan harapan, pelanggan akan puas. Pelangggan yang puas 25 akan setia lebih lama, kurang sensitiv terhadap harga dan memberi komentar yang baik 
terhadap kinerja perusahaan. Untuk menciptakan

kepuasanpelanggan,perusahaan menciptakan dan suatu sistem untuk memperoleh pelanggan yang lebih banyak dari kemampuan untuk mempertahankan pelanggannya.

\section{Energi Listrik}

Energi menurut Eugene C. Lister yang diterjemahkan oleh Hanapi Gunawan (1993) bahwa energi merupakan kemampuan untuk melakukan kerja, energi merupakan kerja tersimpan. Pengertiaan ini tidaklah jauh beda dengan ilmu fisika yaitu sebgai kemampuan melakukan usaha (Kamajaya,
1986). Hukum kekekalan energi menyatakan bahwa energi tidak dapat diciptakan dan tidak dapat pula dimusnahkan. Energi hanya dapat diubah dari suatu bentuk ke bentuk energi yang lain. Demikianlah pula energi listrik yang merupakan hasil perubahan energi mekanik (gerak) menjadi energi listrik.Keberadaan energi listrik ini dapat dimanfaatkan semaksimal mungkin.Adapun kegunaan energi listrik dalam kehidupan seharihari merupakan penerangan, pemanas, motormotor listrik dan lain-lain.Energi yang digunakan alat listrik merupakan laju penggunaan energi (daya) dikalikan dengan waktu selama alat tersebut digunakan.

\section{PEMBAHASAN DAN DISKUSI}

Tabel 4.1. Hasil uji Chi-Square antara karakteristik responden dengan kepuasan pelanggan listrik pascabayar

\begin{tabular}{|c|c|c|c|c|c|}
\hline Koresponden & $\begin{array}{c}\text { Chi-Square } \\
\text { Hitung }\end{array}$ & $\begin{array}{c}\text { Chi-Square } \\
\text { Tabel }\end{array}$ & Hubungan & $\begin{array}{c}\text { P- } \\
\text { Value }\end{array}$ & $\begin{array}{c}\text { Korelasi } \\
\text { Signifikan }\end{array}$ \\
\hline Jenis Kelamin & 0,701 & 5,991 & $\begin{array}{l}\text { Tidak Ada } \\
\text { Hubungan }\end{array}$ & 0,714 & Terima $\mathrm{H}_{0}$ \\
\hline Status & 5,182 & 9,488 & $\begin{array}{l}\text { Tidak Ada } \\
\text { Hubungan }\end{array}$ & 0,297 & Terima $\mathrm{H}_{0}$ \\
\hline Usia & 9,504 & 15,507 & $\begin{array}{l}\text { Tidak Ada } \\
\text { Hubungan }\end{array}$ & 0,312 & Terima $\mathrm{H}_{0}$ \\
\hline Pendidikan & 7,694 & 15,507 & $\begin{array}{l}\text { Tidak Ada } \\
\text { Hubungan }\end{array}$ & 0,472 & Terima $\mathrm{H}_{0}$ \\
\hline Peerjaan & 5,797 & 15,507 & $\begin{array}{l}\text { Tidak Ada } \\
\text { Hubungan }\end{array}$ & 0,686 & Terima $\mathrm{H}_{0}$ \\
\hline Pendapatan & 4,213 & 12,592 & $\begin{array}{l}\text { Tidak Ada } \\
\text { Hubungan }\end{array}$ & 0,682 & Terima $\mathrm{H}_{0}$ \\
\hline Daya Listrik & 1,219 & 5,991 & $\begin{array}{l}\text { Tidak Ada } \\
\text { Hubungan }\end{array}$ & 0,584 & Terima $\mathrm{H}_{0}$ \\
\hline $\begin{array}{l}\text { Lama } \\
\text { Berlangganan }\end{array}$ & 4,027 & 9,488 & $\begin{array}{l}\text { Tidak Ada } \\
\text { Hubungan }\end{array}$ & 0,427 & Terima $\mathrm{H}_{0}$ \\
\hline $\begin{array}{l}\text { Pengeluaran } \\
\text { untuk Listrik }\end{array}$ & 9,798 & 15,507 & $\begin{array}{l}\text { Tidak Ada } \\
\text { Hubungan }\end{array}$ & 0,293 & Terima $\mathrm{H}_{0}$ \\
\hline $\begin{array}{l}\text { Lama } \\
\text { Domisili }\end{array}$ & 1,821 & 9,488 & $\begin{array}{l}\text { Tidak Ada } \\
\text { Hubungan }\end{array}$ & 0,791 & Terima $\mathrm{H}_{0}$ \\
\hline $\begin{array}{l}\text { Pemadaman } \\
\text { Listrik }\end{array}$ & 5,213 & 12,592 & $\begin{array}{l}\text { Tidak Ada } \\
\text { Hubungan }\end{array}$ & 0,582 & Terima $\mathrm{H}_{0}$ \\
\hline $\begin{array}{l}\text { Jumlah } \\
\text { Anggota } \\
\text { Keluarga }\end{array}$ & 7,093 & 12,592 & $\begin{array}{l}\text { Tidak Ada } \\
\text { Hubungan }\end{array}$ & 0,392 & Terima $\mathrm{H}_{0}$ \\
\hline
\end{tabular}

Sumber : Data diolah (2019) 
Uji Chi-Square dalam penelitian digunakan untuk mengetahui hubungan antara karakteristik responden dengan kepuasan pelanggan. Setelah melakukan uji Chi-Square didapatkan hasil bahwa tidak ditemukan korelasi antara karakteristik responden pengguna program listrik pascabayar terhadap kepuasan pelanggan. Berbeda dengan pengguna program listrik prabayar, setelah melakukan uji Chi-Square antara karakteristik responden pengguna program listrik prabayar terhadap kepuasan pelanggan diketahui hasil adanya perbedaan pada jenis kelamin dengan kepuasan pelanggan. Hasil uji chi Square dapat dilihat pada Tabel 4.1 dan 4.2.

Berdasarkan Tabel 4.1, seluruh karakteristik responden listrik pascabayar memiliki hasil Chi-Square hitung $<C h i$ Square tabel dan nilai probabilitas yaitu $P$ value (Asymp. Sig) $>\alpha 0,05$ artinya tidak ada hubungan antara karakteristik responden dengan kepuasan pelanggan listrik pascabayar.

Tabel 4.2 Hasil uji Chi-Square antara karakteristik responden dengan kepuasan pelanggan listrik prabayar

\begin{tabular}{|c|c|c|c|c|c|}
\hline Koresponden & $\begin{array}{c}\text { Chi- } \\
\text { Square } \\
\text { Hitung }\end{array}$ & $\begin{array}{c}\text { Chi- } \\
\text { Square } \\
\text { Tabel }\end{array}$ & Hubungan & $\begin{array}{c}\text { P- } \\
\text { Value }\end{array}$ & $\begin{array}{c}\text { Korelasi } \\
\text { Signifikan }\end{array}$ \\
\hline Jenis Kelamin & 10,7118 & 5,991 & $\begin{array}{c}\text { Ada } \\
\text { Hubungan }\end{array}$ & 0,0039 & Tolak $\mathrm{H}_{0}$ \\
\hline Status & 2,1484 & 9,488 & $\begin{array}{l}\text { Tidak Ada } \\
\text { Hubungan }\end{array}$ & 0,4322 & Terima $\mathrm{H}_{0}$ \\
\hline Usia & 5,3381 & 15,507 & $\begin{array}{l}\text { Tidak Ada } \\
\text { Hubungan }\end{array}$ & 0,7531 & Terima $\mathrm{H}_{0}$ \\
\hline Pendidikan & 10,8476 & 15,507 & $\begin{array}{l}\text { Tidak Ada } \\
\text { Hubungan }\end{array}$ & 0,2768 & Terima $\mathrm{H}_{0}$ \\
\hline Peerjaan & 10,5492 & 15,507 & $\begin{array}{l}\text { Tidak Ada } \\
\text { Hubungan }\end{array}$ & 0,2943 & Terima $\mathrm{H}_{0}$ \\
\hline Pendapatan & 8,5964 & 12,592 & $\begin{array}{l}\text { Tidak Ada } \\
\text { Hubungan }\end{array}$ & 0,2109 & Terima $\mathrm{H}_{0}$ \\
\hline Daya Listrik & 5,8624 & 5,991 & $\begin{array}{l}\text { Tidak Ada } \\
\text { Hubungan }\end{array}$ & 0,2167 & Terima $\mathrm{H}_{0}$ \\
\hline $\begin{array}{l}\text { Lama } \\
\text { Berlangganan }\end{array}$ & 3,4967 & 9,488 & $\begin{array}{l}\text { Tidak Ada } \\
\text { Hubungan }\end{array}$ & 0,7829 & Terima $\mathrm{H}_{0}$ \\
\hline $\begin{array}{l}\text { Pengeluaran } \\
\text { untuk Listrik }\end{array}$ & 9,1927 & 15,507 & $\begin{array}{l}\text { Tidak Ada } \\
\text { Hubungan }\end{array}$ & 0,3217 & Terima $\mathrm{H}_{0}$ \\
\hline Lama Domisili & 3,8372 & 9,488 & $\begin{array}{l}\text { Tidak Ada } \\
\text { Hubungan }\end{array}$ & 0,4527 & Terima $\mathrm{H}_{0}$ \\
\hline $\begin{array}{l}\text { Pemadaman } \\
\text { Listrik }\end{array}$ & 7,6214 & 12,592 & $\begin{array}{l}\text { Tidak Ada } \\
\text { Hubungan }\end{array}$ & 0,2622 & Terima $\mathrm{H}_{0}$ \\
\hline $\begin{array}{l}\text { Jumlah Anggota } \\
\text { Keluarga }\end{array}$ & 3,8297 & 12,592 & $\begin{array}{l}\text { Tidak Ada } \\
\text { Hubungan }\end{array}$ & 0,7126 & Terima $\mathrm{H}_{0}$ \\
\hline
\end{tabular}

Sumber : Data diolah (2019)

Berdasarkan Tabel 4.2. Ditemukan

kepuasan pelanggan. Korelasi ini dapat dilihat pada hasil nilai Chi-Square hitung adanya korelasi antara jenis kelamin dengan

$>$ Chi-Square tabel atau dari P-value 
(Asymp. Sig) 0,0039 < 0,05 maka H1 diterima. Dengan hasil tersebut berarti ada hubungan antara jenis kelamin dengan kepuasan pelanggan. Interpretasi hasil tersebut adalah adanya perbedaan kepuasan antara pelanggan laki-laki dan perempuan, ditemukan bahwa pelanggan laki-laki memiliki nilai kepuasan yang lebih tinggi dalam penggunaan listrik prabayar. Hasil dari pengamatan langsung, pelanggan dengan jenis kelamin laki-laki lebih menyukai program listrik prabayar karena dinilai lebih mudah dalam melakukan pembayaran, penggunaan dan pengawasan listrik serta tidak perlu adanya pemeriksaan meter tiap bulan oleh pihak PT PLN (Persero) sehingga privasi lebih terjamin.

\section{Uji T (T-Test)}

Berdasarkan hasil T-test didapatkan hasil bahwa nilai pada masing-masing dimensi kepuasan pelanggan listrik pascabayar dan listrik prabayar yang meliputi indikator kehandalan (reliability), daya tanggap (responsiveness), jaminan (assurance), bukti fisik (tangible) dan kepedulian (empathy) berbeda signifikan antara kepuasan pelanggan listrik pascabayar dengan pelanggan listrik prabayar, dimana tingkat kepuasan pelanggan listrik prabayar lebih tinggi daripada pelanggan listrik pascabayar, seperti terlihat pada Tabel 4.3.

Tabel 4.3. Hasil Uji T (T-Test)

\begin{tabular}{|c|c|c|c|c|c|c|c|c|}
\hline \multirow[b]{2}{*}{ Dimensi } & \multirow[b]{2}{*}{$\begin{array}{c}\text { T- } \\
\text { Hitun } \\
\mathbf{g}\end{array}$} & \multirow[b]{2}{*}{$\underset{\mathbf{T}}{\text { Sig. }}$} & \multirow[b]{2}{*}{$\begin{array}{c}\text { T- } \\
\text { Tabe } \\
\mathbf{l}\end{array}$} & \multicolumn{2}{|c|}{ Prabayar } & \multicolumn{2}{|c|}{ Pascabayar } & \multirow[b]{2}{*}{$\begin{array}{c}\text { Mean } \\
\text { Differenc } \\
\text { e }\end{array}$} \\
\hline & & & & $\begin{array}{c}\text { Mea } \\
\mathbf{n}\end{array}$ & $\begin{array}{c}\text { Std. } \\
\text { Deviatio } \\
n\end{array}$ & $\begin{array}{c}\text { Mea } \\
\mathbf{n}\end{array}$ & $\begin{array}{c}\text { Std. } \\
\text { Deviatio } \\
n\end{array}$ & \\
\hline Reliability & 2,014 & $\begin{array}{c}0,04 \\
2\end{array}$ & 1,980 & 3,724 & 0,593 & 3,503 & 0,593 & 0,221 \\
\hline $\begin{array}{c}\text { Responsivenes } \\
S\end{array}$ & 2,724 & $\begin{array}{c}0,02 \\
4\end{array}$ & 1,980 & 3,714 & 0,585 & 3,486 & 0,637 & 0,228 \\
\hline Assurance & 1,427 & $\begin{array}{c}0,19 \\
2\end{array}$ & 1,980 & 3,797 & 0,497 & 3,697 & 0,570 & 0,100 \\
\hline Tangible & 3,001 & $\begin{array}{c}0,00 \\
2\end{array}$ & 1,980 & 3,889 & 0,508 & 3,596 & 0,597 & 0,293 \\
\hline Empathy & 4,034 & $\begin{array}{c}0,00 \\
0\end{array}$ & 1,980 & 4,103 & 0,575 & 3,597 & 0,609 & 0,506 \\
\hline
\end{tabular}

Sumber : Data diolah (2019) 
Pada Tabel 4.3 memperlihatkan dimensi reliability, responsiveness, tangible dan empathy didapatkan hasil nilai t-hitung $>\mathrm{t}-$ tabel dan nilai signifikansi $<0,05$. Sehingga dapat didefinisikan adanya perbedaan tingkat kepuasan antara responden listrik prabayar dan listrik pascabayar. Sedangkan untuk dimensi assurance memiliki nilai $\mathrm{t}$ hitung $<\mathrm{t}$ tabel atau nilai prob > alpha 0,05 artinya tidak ada perbedaan yang signifikan tentang kepuasan dimensi assurance antararesponden listrik prabayar dan listrik pascabayar. Nilai mean difference yang positif dapat diartikan bahwa rata-rata kepuasan responden listrik prabayar lebih tinggi dibandingkan rata-rata responden pelanggan listrik pascabayar. Dari hasil analisis t-test tersebut, maka dibuat persentase perbandingan tingkat kepuasan antara responden prabayar dan pascabayar dalam bentuk grafik pada masing-masing variabel seperti berikut :

\section{Reliability (Kehandalan)}

Dimensi reliability merupakan kemampuan perusahaan untuk memberikan pelayanan yang dijanjikan dan seberapa jauh perusahaan tersebut memberikan pelayanan yang akurat (Rasyida, 2016).

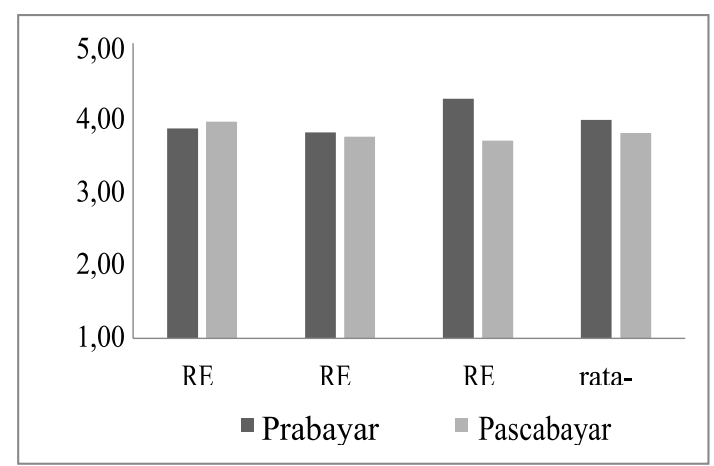

Gambar 4.1. Grafik T-test Reliability

Sumber: Data diolah (2019)

Pada Gambar 4.1 menunjukan grafik perbandingan tingkat kepuasan responden listrik pascabayar dan listrik prabayar pada aspek reliability. Pada gambar tersebut terlihat bahwa tingkat kepuasan pelanggan listrik prabayar lebih tinggi dibandingkan dengan tingkat kepuasan pelanggan listrik pascabayar pada hasil rata-rata item pertanyaan. Uji beda memberikan nilai thitung > t-tabel yaitu 2,014 dan nilai signifikansi $0,042(\mathrm{p}<0,05)$ sehingga diartikan terdapat perbedaan tingkat kepuasan pelanggan listrik prabayar dan listrik pascabayar pada aspek reliability.

\section{Responsiveness (Daya Tanggap)}

Dimensi responsiveness merupakan daya tanggap dalam memberikan pelayanan yang cepat atau responsif serta diiringi dengan cara penyampaian yang jelas dan mudah dimengerti (Rasyida, 2016).

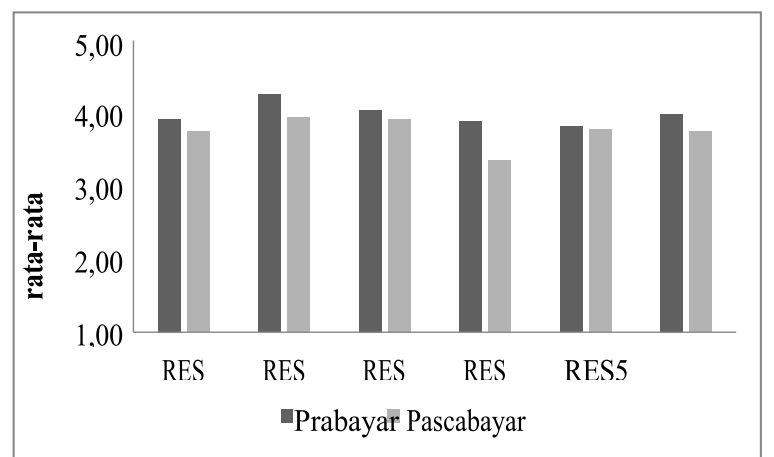

Gambar 4.2 Grafik T-test Responsiveness Sumber: Data diolah (2019)

Pada Gambar 4.2 menunjukan grafik perbandingan tingkat kepuasan responden listrik pascabayar dan listrik prabayar pada aspek responsiveness. Pada gambar tersebut terlihat bahwa tingkat kepuasan pelanggan listrik prabayar lebih tinggi dibandingkan dengan tingkat kepuasan pelanggan listrik pascabayar pada hasil rata-rata item pertanyaan. Uji beda memberikan nilai $\mathrm{t}$ hitung > t-tabel yaitu 2,724 dan nilai signifikansi $0,024(\mathrm{p}<0,05)$ sehingga diartikan terdapat perbedaan tingkat kepuasan pascabayar dan prabayar pada aspek responsiveness.

\section{Assurace (Jaminan )}

Dimensi assurance merupakan jaminan dan kepastian yang diperoleh dari sikap sopan santun karyawan, komunikasi yang baik dan pengetahuan yang dimiliki sehingga mampu menumbuhkan rasa percaya pelanggan (Rasyida, 2016). 


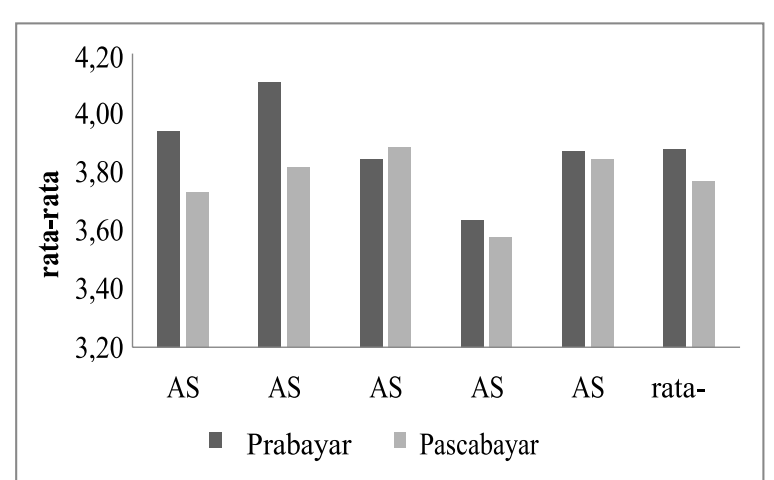

Gambar 4.3. Grafik T-test Assurance

Sumber: Data diolah (2019)

Gambar 4.3 menunjukan grafik perbandingan tingkat kepuasan responden listrik pascabayar dan listrik prabayar pada aspek Assurance. Untuk dimensi assurance memiliki nilai $\mathrm{t}$ hitung $<\mathrm{t}$ tabel atau nilai prob > alpha 0,05 yaitu $1,427<1,980$ dan $0,192>0,05$ artinya tidak ada perbedaan persepsi yang signifikan terhadap kepuasan dimensi assurance antara responden listrik prabayar dan listrik pascabayar.

\section{Tangible ( Berwujud)}

Dimensi tangible merupakan bukti konkret kemampuan suatu perusahaan untuk menampilkan yang terbaik bagi pelanggan. Baik dalam segi fisik tampilan, bangunan, fasilitas, perlengkapan, teknologi pendukung, hingga penampilan karyawan (Rasyida, 2016).

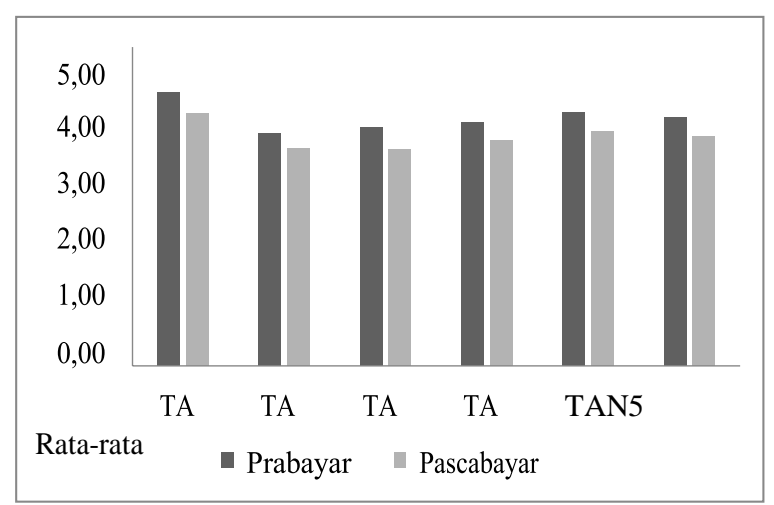

Gambar 4.4. Grafik T-test Tangible

Sumber: Data diolah (2019)

Pada Gambar 4.4 menunjukan grafik perbandingan tingkat kepuasan responden listrik pascabayar dan listrik prabayar pada aspek tangible. Pada gambar tersebut terlihat bahwa tingkat kepuasan pelanggan listrik prabayar lebih tinggi dibandingkan dengan tingkat kepuasan pelanggan listrik pascabayar pada hasil rata-rata item pertanyaan. Uji beda memberikan nilai thitung $>$ t-tabel yaitu 3,001 > 1,980 dan nilai signifikansi $0,002(\mathrm{p}<0,05)$ sehingga diartikan terdapat perbedaan tingkat kepuasan listrik pascabayar dan listrik prabayar pada aspek tangible.

\section{Empathy (Empati)}

Dimensi emphaty merupakan pemberian perhatian yang tulus dan bersifat pribadi kepada pelanggan, hal ini dilakukan untuk mengetahui keinginan pelanggan secara akurat dan spesifik dan melakukan tindak lanjut demi kepentingan pelanggan (Rasyida, 2016).

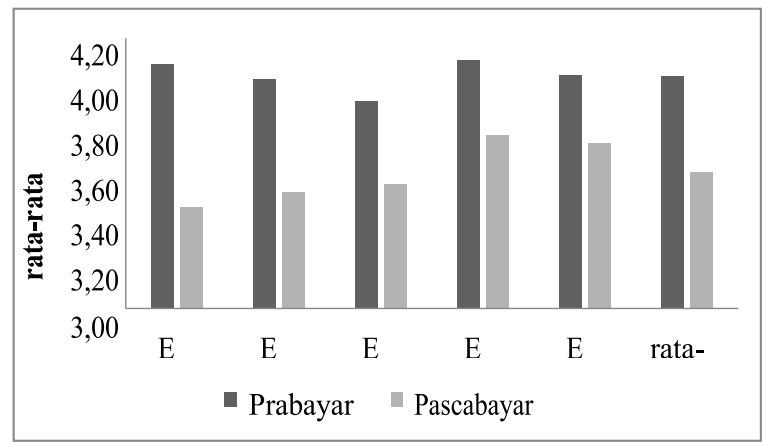

Gambar 4.5. Grafik T-test Empathy Sumber: Data diolah (2019)

Pada Gambar 4.5 menunjukan grafik perbandingan tingkat kepuasan responden listrik pascabayar dan listrik prabayar pada aspek empathy. Pada gambar tersebut terlihat bahwa tingkat kepuasan pelanggan listrik prabayar lebih tinggi dibandingkan dengan tingkat kepuasan pelanggan listrik pascabayar pada hasil rata-rata item pertanyaan. Uji beda memberikan nilai thitung > t-tabel yaitu 4,034 dan nilai signifikansi $0,000(\mathrm{p}<0,05)$ sehingga diartikan terdapat perbedaan tingkat kepuasan listrik pascabayar dan listrik prabayar pada aspek empathy. 
Hasil dari uji T-test didapatkan hasil bahwa rata-rata kepuasan responden listrik prabayar lebih tinggi dibandingkan rata-rata kepuasan responden listrik pascabayar dikarenakan dalam program listrik prabayar tidak ada beban listrik bulanan dan minimal pemakaian, penggunaan sistem digital yang lebih akurat, pemakaian lebih terkontrol dibandingkan listrik pascabayar dimana menggunakan listrik prabayar dituntut untuk lebih hemat, pengeluaran lebih ekonomis terbukti dengan dominasi responden listrik prabayar dengan tingkat pendapatan dibawah Upah Minimum Regional (UMR) yang lebih memilih program listrik prabayar karena alasan efisiensi dalam pemakaian, privasi kehidupan pelanggan, pelanggan terlepas dari masalah kesalahan pencatatan meter dan terbebas dari sanksi pemutusan atau denda keterlambatan yang secara otomatis mengatasi keluhan pelanggan mengenai pembacaan meter yang tidak akurat, dan lebih dari setengah responden listrik prabayar adalah pelanggan mutasi yang pernah merasakan program listrik pascabayar namun berpindah ke listrik prabayar karena listrik prabayar lebih efisien dan efektif serta memiliki sedikit kelemahan dalam pemakaian.

\section{KESIMPULAN}

Berdasarkan analisis di atas, dapat ditarik 5 (lima) kesimpulan, yaitu:

1. Berdasarkan uji korelasi chi square untuk karakteristik pelanggan pascabayar dengan kepuasan diperoleh hasil bahwa tidak ada korelasi karakteristik responden dengan kepuasannya responden, sedangkan untuk pelanggan prabayar didapatkan hasil bahwa hanya karakteristik pelanggan jenis kelamin yang memiliki korelasi dengan kepuasan responden

2. Berdasarkan hasil pengujian T-test diketahui bahwa ada perbedaan, tingkat kepuasan pelanggan terhadap pelayanan di PT PLN (Persero) Area Purwokerto. Hasil perbandingan nilai rata-rata tingkat kepuasan pelanggan pascabayar dan prabayar secara keseluruhan

3. Menyatakan bahwa pelanggan prabayar memiliki nilai rata-rata lebih tinggi dibandingkan dengan pelanggan pascabayar.

4. Tingkat kepentingan dan tingkat kepuasan pada dimensi realibility, responsiveness, assurance, tangible dan emphaty pada pelanggan listrik prabayar lebih tinggi daripada tingkat kepentingan dan tingkat kepuasan pelanggan listrik pascabayar.

5. Berdasarkan hasil T-Test, permintaan listrik prabayar memberikan kepuasan yang lebih besar daripada listrik pascabayar

Aturan baru pemasangan listrik prabayar lebih diarahkan kepada pelanggan listrik baru, akan tetapi masih banyak masyarakat yang enggan bermigrasi dari layanan pascabayar ke layanan prabayar. Masyarakat enggan berpindah karena banyak alasan, walaupun sebenarnya penggunaan listrik prabayar lebih praktis daripada listrik pascabayar. Untuk itu perlu adanya upaya agar masyarakat mau bermigrasi ke listrik prabayar dengan sebagai berikut:

a. Sosialisasi kemudahan penggunaan listrik prabayar secara menyeluruh dan mendalam pada lingkungan masyarakat.

b. Penyebarluasan informasi dalam bentuk tulisan, iklan dan bentuk promosi lainnya terhadap masyarakat tentang fitur-fitur listrik prabayar. 


\section{DAFTAR PUSTAKA}

Herman, dan Hasanbasri, Mubasysyi. 2008. Evaluasi Kebijakan Penempatan Tenaga Kesehatan di Puskesmas Sangat Terpencil di Kabupaten Buton. Jurnal Manajemen Pelayanan Kesehatan. Vol. 11:

Ekawati, Sulistya. 2013. Evaluasi Implementasi Kebijakan Desentralisasi Pengelolaan Hutan Produksi. Jurnal Analisis Kebijakan Kehutanan. Vol. 10(3):

Nurharjadmo, Wahyu. 2008. Evaluasi Implementasi Kebijakan Pendidikan Sistem Ganda di Sekolah Kejuruan. Jurnal Spirit Publik. Vol. 4(2):

Handok, Rudi dan Patriadi, Pandu. 2005. Evaluasi Kebijakan Subsidi NonBBM.Jurnal Kajian Ekonomi dan Keuangan. Vol. 9(4)

Sartika, Ika. 2008. Evaluasi Implementasi Kebijakan Pendidikan Sistem Ganda Di Sekolah Kejuruan. Jurnal Ilmu Administrasi Negara. Vol. 11(2):

Putri, Noventi, Ersa, dan Iskandar. 2014. Analisis Preferensi Konsumen Dalam Penggunaan Social Messenger Di Kota Bandung Tahun 2014. Jurnal Manajemen Indonesia. Vol. 14(2)

Rosipah, Sitti, Burhan, dan Purwandari, Umi. 2013. Preferensi Konsumen Terhadap Pancake Dari Tepung Sukun. Jurnal Agrointek. Vol 7(1)

Asribestari, Ratna, dan Setyono. Pengaruh Daya Tarik Pasar Tradisional dan Pasar Modern Terhadap Preferensi Masyarakat. Jurnal Teknik PWK. Vol 2(3)

Anggasari, Poppy, Yulianti, dan Retnaningsih. Pengaruh Ethnosentrisme Terhadap Sikap, Preferensi dan Perilaku Pembelian Buah Lokal dan Impor. Jurnal Manajemen \& AgribisniI. Vol. 10(2)

Rusma, Jimmy, Hubeis, Musa, dan Suharjo. Kajian Preferensi Konsumen Rumah Tangga Terhadap Beras Organik di Wilayah Kota Bogor. Jurnal Manajemen IKM. Vol. 6(1)
Ramadlana, Rasyida Leila dan Najib, Mukhamad. 2016. Analisis Perbedaan Kualitas Pelayanan Listrik Pascabayar dan Listrik Prabayar terhadap Kepuasan Pelanggan Pada PT PLN (Persero) Area Ciputat. Jurnal Manajemen dan Organisasi Vol 7 (3). 